Folia Historica Cracoviensia, 22: 2016, s. 399-418

DOI: http://dx.doi.org/10.15633/fhc.2087

Grażyna Ryba

UNIWERSYTET RZESZOWSKI

\title{
Kościół bernardynów w Rzeszowie. Mistagogia przestrzeni prowadzącej do wnętrza świątyni
}

W latach 1610-1629 z fundacji Mikołaja Spytka Ligęzy wzniesiono w Rzeszowie na miejscu objawień Matki Boskiej kościół, nad którym opiekę powierzono bernardynom (il. 1) ${ }^{1}$. Jest to budowla orientowana, zbudowana na planie krzyża łacińskiego, $\mathrm{z}$ dwuprzęsłową nawą, transeptem kryjącym dwie kaplice oraz jednoprzęsłowym prezbiterium, zamkniętym półkolistą absydą (il. 2). Od zachodu na osi budowli znajduje się wyniosła czworoboczna wieża, natomiast XVIII-wieczne zabudowania klasztorne przylegają do bryły kościoła od północy (1702-1707, Pietro Belotti wg proj. Tylmana z Gameren). Skrzyżowanie nawy i transeptu podkreśla podwójnie spiętrzona latarnia kopuły wtopionej w dwuspadowy dach. Elewacje budowli zdobią proste, płaskie podziały w postaci lizen i gzymsów, a otwory okienne ujęto w skromne obramienia. Otwory strzelnicze (ambrazura kluczowa) pod gzymsem koronującym przypominają, że kościół stanowił ważny element w systemie obronnym miasta, pełniąc funkcję cytadeli narożnej osłaniającej ciąg murów miejskich.

Wojewódzki Urząd Ochrony Zabytków w Rzeszowie, Karta Ewidencyjna Zabytków Architektury i Budownictwa, Kościół oo. Bernardynów w Rzeszowie, oprac. J. Malczewski, 10.01.1993. Wybrane opracowania: A. Fischinger, P. Krakowski, Kościół Bernardynów w Rzeszowie - mauzoleum Ligęzów, [w:] Studia renesansowe, t. 3, red. M. Walicki, Wrocław 1963, s. 150-202; K. Majewski, Z badań nad sztuka Rzeszowa, [w:] Dzieje Rzeszowa, t. 1, red. F. Kiryk, Rzeszów 1994, s. 411413, 458-468, 487-508; Kościoly, klasztory i parafie dawnego Rzeszowa. materiały $z$ konferencji naukowej zorganizowanej dla uczczenia Wielkiego Jubileuszu Chrześcijaństwa, 15-16 XI 2000 r., red. M. Jarosińska, Rzeszów 2001; W. Hennig, Kościół oo. Bernardynów, [w:] Encyklopedia Rzeszowa, red. J. Draus i in., Rzeszów 2004, s. 246-249 (też kolejne wydania); W. P. Tokarski ofM, E. Kurowska, Bazylika Ojców Bernardynów w Rzeszowie. Przewodnik, Rzeszów 2009. 
Z prostotą bryły zewnętrznej świątyni kontrastuje bogactwo wystroju wnętrza (il. 3), pomyślanego pierwotnie jako mauzoleum rodowe Ligęzów, którego pozostałością jest manierystyczny ołtarz główny ze scenami pasyjnymi i posągi przedstawicieli rodu, klęczących w pozie wiecznej adoracji we wnękach w ścianach prezbiterium. Z połowy XVIII wieku pochodzą bogate późnobarokowe ołtarze boczne, ambona, chór muzyczny oraz wystrój kaplic; nieco później wykonano iluzjonistyczne malowidła ze sceną wniebowzięcia Najświętszej Marii Panny na sklepieniu nawy. Główne wejście do kościoła znajdowało się z boku, w południowej elewacji wieży, i tak też zostało przedstawione na planie Rzeszowa ukazującym widok świątyni, który wykonał Karol Wiedemann w 1762 roku (il. 4).

W związku z jubileuszem 50o-lecia objawień na tym miejscu Matki Boskiej, przypadającym w 2013 roku, w kościele dokonano szeregu prac renowacyjnych ${ }^{2}$. W kruchcie, która zajmuje dolną kondygnację wieży, na osi na wprost prezbiterium odkryto wejście, zamurowane prawdopodobnie wkrótce po wybudowaniu kościoła, i przebito je ponownie, zgodnie z pierwotnym założeniem. W otworach drzwiowych sukcesywnie umieszczano w latach 2010, 2012 i 2013 brązowe rzeźbione wrota wykonywane przez miejscową rzeźbiarkę Zofię Mitał ${ }^{3}$. Złożony program ikonograficzny zdobiących je przedstawień został wypracowany przez artystkę wspólnie z ówczesnym proboszczem parafii bernardyńskiej o. Rafałem Klimasem ${ }^{4}$.

Pomieszczenie kruchty w przyziemiu wieży zajmuje przestrzeń na planie zbliżonym do kwadratu, przykryta sklepieniem krzyżowym (il. 2). W każdej ścianie znajduje się otwór wejściowy wypełniający wnękę w grubości muru zamkniętą łukiem odcinkowym. Dwie pary dwuskrzydłowych drzwi z brązu, obustronnie rzeźbionych, prowadzą do wnętrza kruchty z zewnątrz, natomiast kolejne drzwi, również pokryte dekoracją rzeźbiarską, oddzielają to pomieszczenie od nawy. Ich częściowe przeszklenie sprawia, że w kształt pola obrazowego zostaje wpisane całe wnętrze bogatej manierystyczno-barokowej budowli, tworząc przestrzenny

M.in. konserwacja polichromii i ołtarza głównego oraz kaplic bocznych (por. B. Jagiela, B. Gosztyła, Restauracja ołtarza głównego w kościele oo. Bernardynów w Rzeszowie, „Wiadomości Konserwatorskie" 40 (2014), s. 7-13; sprawozdania z kolejnych etapów prac w Kronice parafialnej parafii Wniebowzięcia NMP w Rzeszowie oraz na stronie: http://www.bernardyni.rzeszow.pl (22.03.2015).

3 Artystka jest także autorką rzeźbionych drzwi brązowych w kościołach katedralnych w Rzeszowie i Przemyślu. Por. M. Nikiel, Mitał Zofia, [w:] Encyklopedia..., dz. cyt., s. 327; G. Ryba, Katedra rzeszowska 1977-2002. Historia, sztuka, twórcy, idee, Kraków 2007, s. 184-204.

4 Na podstawie rozmów przeprowadzonych z o. Rafałem Klimasem i Zofią Mitał w marcu 2015 roku. 
układ scenograficzny, rozwijający się w głąb, aż do tabernakulum i ołtarza głównego w prezbiterium. $Z$ natury rzeczy ruchomy układ skrzydeł pozwala tworzyć zmienne konfiguracje o zróżnicowanym przesłaniu, rozwijającym się w czasie i przestrzeni. Obrazy $z$ historii lokalnego objawienia i postaci miejscowych świętych poprzez przedstawienia i cytaty biblijne stopniowo prowadzą widza do tajemnicy wcielenia.

Przestrzeń kruchty, łącząca umiejętnie przekaz ikonograficzny z symboliką i ekspresją formy (m.in. symbolika światła i symbolika materiału) stanowi znaczący element, a zarazem metaforę wtajemniczenia mistagogicznego, dokonującego się podczas przekraczania granicy pomiędzy profanum a sacrum. Zamieszczony poniżej tekst zawiera opis i próbę interpretacji przedstawień na drzwiach kościoła bernardynów w Rzeszowie w duchu współczesnej mistagogii chrześcijańskiej, znajdującej odzwierciedlenie w dokumentach Kościoła.

Od strony alei Łukasza Cieplińskiego (jednej z najważniejszych arterii Rzeszowa) ku głównemu wejściu do kościoła Wniebowzięcia Najświętszej Marii Panny (obecnie w zachodniej elewacji wieży) znajdują się rzeźby - znaki wprowadzające w charyzmat miejsca - sanktuarium maryjnego, pozostającego pod opieką zakonu oo. bernardynów. Przy skrzyżowaniu ulic umieszczono statuę, która jest kopią Madonny z Dzieciątkiem czczonej w świątyni, a w pobliżu wejścia do kościoła - figurę bernardyńskiego zakonnika - św. Jana z Dukli.

Drzwi z brązu w zachodniej elewacji wieży wieńczy tablica, wykonana $\mathrm{z}$ tego samego materiału, zawierająca godność i patrocinium świątyni: Bazylika Mniejsza Wniebowzięcia Najświętszej Marii Panny. Na murze po obu stronach drzwi umieszczono kolejne tablice, zawierające fragmenty dekretów papieskich i biskupich, odnoszących się do godności świątyni jako bazyliki mniejszej. Pole obrazowe zajmuje oba skrzydła drzwi, pozbawione wewnętrznych podziałów (il. 5). Zostało ono zdominowane przez wyobrażenie „opowieści założycielskiej” kościoła ${ }^{5}$ a sylwetka Matki Boskiej Rzeszowskiej stanowi oś kompozycyjną całości. W górze, wśród konarów gruszy, ukazano posąg Madonny, znajdujący się w kaplicy wewnątrz kościoła. Poniżej wizerunku Madonny klęczy Jakub Ado,

5 Według terminologii wprowadzonej i stosowanej przez A. Kramiszewską w: Prawdziwie jest to dom Boga i brama do nieba! Opowieść etiologiczna miejsc świętych $w$ zwierciadle sztuki, Lublin 2012. 
mieszczanin rzeszowski z rodziną, któremu 15 sierpnia 1513 roku objawiła się Matka Boska, wyrażając życzenie: „Pragnę na tym miejscu chwałę Syna mego widzieć i nieść pocieszenie strapionym”. Słowa te wyryto na ołtarzu, przedstawionym w dole po lewej. Obok skupili się polscy święci bernardyńscy: o płytę ołtarza opiera się św. Szymon z Lipnicy, przyciskając do piersi ampułkę z olejami świętymi, obok niego klęczy św. Jan z Dukli, a z drugiej strony, w głębi, ukazani zostali błogosławieni Ładysław z Gielniowa trzymający figurkę ubiczowanego Chrystusa i Anastazy Pankiewicz z krucyfiksem i koroną cierniową na więziennym pasiaku’. Spoza sylwetek świętych wyłaniają się: husarskie skrzydła, napierśnik i ryngraf, krzyż Orderu Virtuti Militari, proporce i sztandary wojskowe, które mają przypominać, że święto Wniebowzięcia Najświętszej Marii Panny związane z objawieniem Madonny w Rzeszowie i patrocinium kościoła jest także dniem wojska polskiego. Spod ołtarza, w dole, jako źródło łask i bogactwa okolicy wypływa struga, obfitująca w ryby i inne stworzenia rzeczne; przechodzi ona stopniowo w roślinność nadbrzeżną, a ta z kolei łączy się w bukiet ziól, święconych w dniu Matki Boskiej Zielnej, jak w ludowej pobożności nazywane bywa święto obchodzone 15 sierpnia. Od postaci Madonny biją promienie, ale jednocześnie spływa na Nią z góry snop światła, złożony z trzech różnych układów linii, symbolizujących Trójcę Świętą ${ }^{8}$. Pomiędzy nimi widnieje tekst pierwszych słów Pozdrowienia Anielskiego: Ave Maria gratia plena. Całości sceny dopełniają w dole przedstawienia herbów: miasta Rzeszowa i Ligęzów - fundatorów kościoła. Promienie dynamizują całość przedstawienia wydobytego mocnymi, wyrazistymi liniami, które modelują silnie cieniujące, rozczłonkowane elementy płaskorzeźby, w niektórych partiach wydobywając kształty rzeźby półpełnej, a nawet, jak figurka Madonny, niemal pełniej.

Dekoracja awersu głównego wejścia, które jest na co dzień zamknięte, stanowi jakby pierwszy stopień (etap) wprowadzenia w historię zbawienia - mówi o obecności Boga, wkraczającego w życie społeczności lokalnej (objawienie Madonny) i obecnego w historii narodu (sztandary wojskowe), w zwyczajach ludowych (bukiet ziół), a także działalności świętych i błogosławionych.

6 W. P. Tokarski, E. Kurowska, Bazylika..., dz. cyt., s. 3-4.

Według informacji rzeźbiarki (por. przyp. 4). Rozpoznanie Ładysława z Gielniowa ułatwia atrybut w postaci figurki biczowanego Chrystusa, wskazujący na cechujący tę postać kult Męki Pańskiej (por. W. Zaleski sDB, Święci na każdy dzień, Warszawa 1989, s. 366-369), a na Atanazego Pankiewicza, więźnia Dachau, wskazuje m.in. jego numer obozowy (J. Bystroń, Polscy święci i błogosławieni wyniesieni na ołtarze przez Jana Pawła II, Pelplin 2004).

${ }^{8}$ Por. przyp. 4. 
Dekoracja rewersu drzwi stanowi również kompozycję, która wypełnia, bez podziałów na mniejsze pola, oba skrzydła drzwi i jest możliwa do odczytania w całości tylko od wewnątrz budowli, po przekroczeniu progu kruchty (il. 6).

$\mathrm{Na}$ wewnętrznej stronie drzwi ukazano cztery sylwetki anielskie (archaniołów), wyłaniające się z wiru utworzonego wokół realistycznie opracowanego oka Opatrzności Bożej, które znajduje się w centrum kompozycji. Z przodu wyobrażono dwie postaci wbiegające w pędzie do wnętrza. Jedna $z$ nich to Michał o czujnym spojrzeniu spod zmarszczonych brwi, ukazany w zbroi z mieczem i tarczą jako wojownik stojący na czele zastępów anielskich ${ }^{9}$. Kula ziemska pod jego stopami i układ miecza w pozycji tzw. sparowanej mają symbolizować ochronę ludzkości przed siłami zła. Obok niego biegnie Gabriel ${ }^{10}$ o jasnym spojrzeniu szeroko otwartych oczu; w dłoni trzyma lilię, symbol czystości i prawdy, a $\mathrm{w}$ drugiej - taśmę z napisem „Emmanuel”, przypominającym jego funkcję zwiastuna Dobrej Nowiny. Do pasa ma przytroczone naczynie z wodą symbolizujące obmycie człowieka z grzechu, które stało się możliwe dzięki wcieleniu. Obaj archaniołowie wyobrażają początek i koniec dziejów zbawienia. Gabriel stoi u jego początków jako zwiastujący Marii narodziny Jezusa, a Michał ma być obecny przy Sądzie Ostatecznym na końcu świata. Ich wizerunki bywały umieszczane przy wejściu do świątyni jako strzegące przed siłami zła. Za postacią Gabriela ukazano archanioła Rafała ${ }^{11}$ o rysach twarzy Dawida Michała Anioła (wg autorki), trzymającego $\mathrm{w}$ ręku rybę i laskę pielgrzyma $\mathrm{z}$ tykwą, niosącego uzdrowienie duszy i ciała. To trzej archaniołowie kanoniczni, którzy jako jedyni znani z imienia występują na kartach Biblii. Kolejna postać powinna ukazywać tajemniczego anioła Uriela ${ }^{12}$ - światło Boga i ogień Boży, znanego $\mathrm{z}$ apokryfów i czasem w ikonografii towarzyszącego trzem poprzednim. Według autorki jest to anioł stróż uosabiający „czystą ideę anioła” ${ }^{13}$. W jego lewej ręce rodzi się dusza człowieka uosabiana przez sierp księżyca, w sercu uzyskuje swoją pełnię

9 G. Duchet-Suchaut, M. Pastoureau, La Bible et les saints. Guide iconographique, Paris 1990, s. 231-232; Z. Ziółkowski, Michał Archanioł w Piśmie Świętym i życiu Kościoła, Częstochowa 2011; R. Knapiński, Titulus ecclesiae. Ikonografia wezwań współczesnych kościołów katedralnych w Polsce, Warszawa 1999, s. 332-344; M. Bussagli, Aniołowie: pochodzenie, historia, ikonografia istot niebieskich, tłum. A. Gogut, Warszawa 2011, s. 748-752.

${ }^{10}$ G. Duchet-Suchaut, M. Pastoureau, La Bible..., dz. cyt., s. 153-154; M. Bussagli, Aniołowie..., dz. cyt., s. 560-614.

${ }^{11}$ G. Duchet-Suchaut, M. Pastoureau, La Bible..., dz. cyt., s. 291-292; M. Bussagli, Aniołowie..., dz. cyt., s. 270-278, 298-306.

${ }_{12}$ M. Bussagli, Aniołowie..., dz. cyt., s. 302.

${ }_{13}$ Por. przyp. 4. 
i materializuje się, łącząc się z ciałem w prawej dłoni anioła. Całość kompozycji rewersu drzwi, w kolejnym etapie wprowadzenia w tajemnicę zbawienia, wskazuje na opiekę Bożą, roztaczaną także nad wiernymi chroniącymi się w mury rzeszowskiej świątyni.

Postaci anielskie pędzące $\mathrm{z}$ impetem przed siebie wyznaczają kierunek ruchu ku nawie, którą oddzielają od kruchty kolejne drzwi. Są to wewnętrzne drzwi wahadłowe zwane „kryształowymi” zbudowane z brązu, częściowo złoconego, i szkła (il. 7). Składają się one z dwu skrzydeł i nadświetla (supraporty). Tworzące je kompozycje rzeźbiarskie ukazują aniołów oddających hołd imieniu Jezus. Na skrzydłach drzwi sylwetki anielskie tworzą obramienie dla przezroczystych tafli szklanych, otwierających widok na nawę. Na środku wzdłuż krawędzi skrzydeł wyrasta $\mathrm{z}$ ziemi drzewo oliwne przechodzące w górze w złocony krzyż franciszkański w kształcie litery Tau. Jeden z aniołów spoczywa na ziemi i wspiera się na pniu drzewa, w którego korzeniach kryją się szczątki praojca Adama. Pozostali czterej aniołowie unoszą się w górę z rozpostartymi skrzydłami, trzymając w rękach złociste palmy. Jedni odwracają głowy w stronę kruchty, inni spoglądają ku nawie. Ich poruszone dynamiczne sylwetki, silnie rozczłonkowane, są pełnoplastyczne i zdają się rzeczywiście unosić w powietrzu dzięki osadzeniu w przezroczystych taflach szkła. Skrzydła drzwi oddziela od nadświetla listwa z napisem Magnificat anima mea Dominum, zawierającym pierwsze słowa pieśni uwielbienia Marii, zapisane w Ewangelii. W środkowej części nadświetla unosi się złocista hostia $\mathrm{z}$ monogramem $\mathrm{IHS}$, otoczona promieniami i adorowana przez kolejne anioły. Jeden $\mathrm{z}$ nich trzyma złoty kielich, inny tabliczkę z napisem $\mathrm{A} \Omega$. Ekspresyjnie poruszone postaci aniołów korespondują z bogatym, barokowym wystrojem wnętrza, które oddziela od patrzącego tylko tafla szkła. Drzwi „kryształowe" zawierają skrót dziejów ludzkości od Adama do Jezusa i są związane z chryzmatem pobożności franciszkańskiej, a w szczególności zakonu bernardynów, głoszącego w ślad za św. Bernardynem kult imienia Jezus ${ }^{14}$. Połączenie brązu ze złotem i szkłem oraz półmroku kruchty i światła nawy symbolizuje stopniowe przejście ku sferze coraz głębszej transcendencji. Przez tafle szkła widać wnętrze, w którym dominuje blask złota posągów i ornamentów oraz barwy obrazów i polichromii. Kulisowo wysuwające się ołtarze boczne otwierają się ku symbolicznej via solea prowadzącej ku ostatniej bramie - łukowi tęczowemu oddzielającemu nawę od prezbiterium. Architektoniczne konstrukcje ołtarzy ujmują także swoiste bramy wypełnione obrazami, otwierającymi się na przestrzeń bytowania świętych możliwą do przekroczenia wyłącznie na drodze modlitwy i kontemplacji.

\footnotetext{
14 R. Knapiński, Titulus ecclesiae..., dz. cyt., s. 276; W. Zaleski sDB, Święci..., dz. cyt., s. 264-266.
} 
Aby w dzień powszedni wkroczyć w mury świątyni, należy skorzystać z wejścia bocznego znajdującego się w wieży od strony południowej, zamkniętego również przez dwuskrzydłowe drzwi z brązu (il. 9). Otwarta jest zazwyczaj tylko mała furta - porta angusta - wycięta w jednym ze skrzydeł. Jej zarys obejmuje postać św. Franciszka ${ }^{15}$, bosego, w habicie, ze stygmatami na dłoniach, w których trzyma księgę zawierającą regułę zakonu. W aureoli wokół jego głowy zapisano słowa świętego: Deus et omnia, które stały się dewizą zakonów franciszkańskich. Postać św. Franciszka, głoszącego cnotę ubóstwa i umartwienia, na porta angusta nawiązuje do symboliki furty, wywodzącej się z przesłania ewangelicznego o „wąskiej (ciasnej) bramie" wiodącej do zbawienia (Mt 7, 13-14; Łk 13, 24) ${ }^{16}$.

Świętemu Franciszkowi jako twórcy reguły wspólnot franciszkańskich towarzyszą ukazani powyżej w półpostaci: św. Bernardyn ze Sieny, współzałożyciel odłamu obserwanckiego w łonie zakonu, i św. Jan Kapistran, jego uczeń, który przyczynił się do sprowadzenia zreformowanej gałęzi do Polski, gdzie wkrótce zaczęła funkcjonować pod nazwą bernardynów ${ }^{17}$. Święty Bernardyn ze Sieny ${ }^{18}$, którego imię (jako patrona kościoła franciszkanów obserwantów w Krakowie) dało początek polskiej prowincji zakonu, trzyma w ręku tabliczkę z chrystogramem, ponieważ wyróżniał się nabożeństwem do imienia Jezus; na jego piersi widnieje monogram maryjny, a w ręku - otwarta księga, zapewne $\mathrm{z}$ regułą zakonną; w dole leżą trzy infuły przypominające o trzech odrzuconych przez zakonnika biskupstwach. Święty Jan Kapistran ${ }^{19}$ jako słynny kaznodzieja zwycięskiego Kościoła trzyma krucyfiks i chorągiew z krzyżem; nad nim na banderoli widnieją słowa: Deo aut [em] gratias qui dedit nobis victoriam (1 Kor 15). Postaci wymienionych trzech świętych wprowadzających w historię wspólnoty znajdują się na wprost wejścia, które w kruchcie prowadzi do furty klasztornej, a rozwinięcie ich nauczania znajdzie swój wyraz na „drzwiach kryształowych” prowadzących do nawy.

$\mathrm{Na}$ drugiej połaci drzwi dziewięć uskrzydlonych postaci symbolizujących chóry anielskie rozkłada zwój materii, zapewne ze słowami Ewangelii, której fragment, zawierający Magnificat, ukazują oczom widza. Pierwsze słowa tego

15 R. Knapiński, Titulus ecclesiae..., dz. cyt., s. 286-287; W. Zaleski sDB, Święci..., dz. cyt., s. $598-603$.

${ }^{16}$ Por. J. Samek, Porta angusta i nagrobki portalowe w Polsce (zapomniana symbolika wejścia w sztuce), „Folia Historiae Artium” (1980) 16, s. 141-159.

${ }^{17}$ E. Wyczawski, Krótka historia Zakonu Braci Mniejszych, [w:] Klasztory bernardyńskie $w$ Polsce, Kraków 1985, s. 619-631.

18 Por. przyp. 14.

19 W. Zaleski sDB, Święci..., dz. cyt., s. 654-657. 
hymnu Marii napotka on później nad drzwiami „kryształowymi” wewnątrz kruchty. Przechodnia otwierającego drzwi furty i przekraczającego próg świątyni wita wpisana w nie od środka scena Zwiastowania, wprowadzająca w tajemnicę wcielenia (il. 11). Przy lekkim uchyleniu furty postać Madonny koresponduje z tekstem pieśni uwielbienia trzymanym przez anioły, antycypując jakby kolejną scenę ewangeliczną - spotkania z Elżbietą.

W wyobrażeniu Zwiastowania, należącym już do dekoracji wewnętrznej strony drzwi (il. 10), anioł przybywający z gałązka oliwną podnosi w górę dłoń, wskazując Madonnie przyszłość, ujętą w maleńkich scenkach: Nawiedzenia, Bożego Narodzenia, Pokłonu Trzech Króli, Odnalezienia w świątyni i Zmartwychwstania. Nad wszystkim unosi się widmo krzyża z twarzą Chrystusa ujętą pośrodku. Bijące od niej promienie przebiegają po diagonali na drugie skrzydło drzwi i przenikają sylwetkę Madonny, unoszonej do nieba. W dole pozostaje malejący krąg ziemi i wyrastające $z$ niego trzy krzyże. Rozwiane szaty anioła ze Zwiastowania, trzepocąc i skrząc się gwałtownie kładzionymi liniami reliefu, przebiegają na drugie skrzydło, tworząc pierścienie wokół kuli ziemskiej i otaczających ją ciał niebieskich. Unoszona do nieba Madonna ma dłonie złożone do modlitwy i głowę uniesioną do góry. Wpatruje się w imię Boga zapisane czcionką przypominającą hebrajską: „Jam Jest który Jest” (Wj 3, 14).

W trakcie uchylania furty do wnętrza ciemnawej kruchty wpada snop światła, jakby lumen divinis opromieniające Madonnę. Podobne wrażenie powstaje, gdy niekiedy otwierane jest przeciwległe skrzydło, a po promieniach $\mathrm{z}$ brązu zdaje się spływać światło od zapisanego w górnej części skrzydła imienia Boga.

Wchodzący do kruchty przez furtę staje na wprost skromnych drzwi prowadzących do pomieszczeń klasztornych, które poprzedza korytarz, pełniący jednocześnie funkcję kaplicy z okazałym późnorenesansowym krucyfiksem. Na lewo widać wewnętrzną część drzwi głównych, a na prawo - drzwi „kryształowe”, prowadzące do nawy. Podnosząc oczy ku górze, widz napotyka iluzjonistyczne freski barokowe, stanowiące część polichromii, pokrywającej całe wnętrze kościoła $^{20}$. Na sklepieniu ukazano otwarte niebo $\mathrm{z}$ aniołami, a nad poszczególnymi drzwiami znajdują się ujęte $\mathrm{w}$ rokokowe ornamenty emblematy związane z kultem Serca Jezusowego oraz godło franciszkańskie nad wejściem do pomieszczeń klasztornych. Współczesna rzeźba znakomicie dopełnia barokowe malarstwo, ale jednocześnie się mu przeciwstawia na płaszczyźnie symbolu, który wskazuje na wyższy stopień uduchowienia występujący w przejściu od bryły do barwy.

${ }^{20}$ K. Majewski, Z badań..., dz. cyt., s. 458-468. 
Wielu przybywających do świątyni w dzień powszedni zatrzymuje się właśnie w kruchcie. W dzień świąteczny otwierane są na oścież drzwi główne, a często też boczne. Sceny historyczne są niewidoczne, natomiast aniołowie i obrazy z Ewangelii wkraczają w przestrzeń profanum. Dziesiątki ludzi, przechodząc przez drzwi wahadłowe, sprawiają, że postaci anielskie zostają wprawione w ruch, ożywają, mieszają się z tłumem bądź unoszą się nad nim, a wizerunki anielskie na kolejnych drzwiach tworzą wieloplanowy układ, rozbudowując wrażenie ruchu niebiańskich istot w przestrzeni (il. 8). Bardzo często owemu przekraczaniu granicy pomiędzy sacrum i profanum towarzyszy dźwięk muzyki lub śpiew chórów, potęgujący wrażenia estetyczne działające na zmysł wzroku. Wszystkie te elementy należy łączyć $\mathrm{z}$ analizą ruchu w świątyni, rzeczywistego i symbolicznego, jako przechodzenia od widzialnego do niewidzialnego, od wiedzy do doznania obecności nadprzyrodzonej.

Poszczególne zespoły elementów symbolicznych układają się wzdłuż dwu osi przestrzenno-tematycznych przecinających się wewnątrz kruchty. Oś główna ukazuje na zewnątrz konkretne przykłady opieki Bożej w określonej społeczności, następnie we wnętrzu kruchty, czyli przestrzeni granicznej, następuje przeniesienie tej problematyki na pewien stopień abstrakcji odwołującej się do działania Opatrzności Bożej w odniesieniu do całej ludzkości, a w progu nawy, czyli właściwego wnętrza sacrum, prowadzi do adoracji, wymagającej modlitewnego skupienia i wiedzy teologicznej związanej z rozważaniem samej istoty Boga.

Oś poprzeczna łączy odniesienia do Marii i charyzmatu zakonu wyobrażonego na zewnątrz w postaciach jego ojców założycieli i najwybitniejszych przedstawicieli. Magnificat na zewnątrz stanowi zapowiedź ewangelicznej opowieści o życiu Matki Boskiej na wewnętrznej stronie drzwi, ze szczególnym wyróżnieniem sceny Wniebowzięcia, związanego ze świętem patronalnym kościoła. Święci franciszkańscy wskazują drogę do klasztoru ukrytą za kolejnymi drzwiami.

Przedsionek, czyli kruchta, stanowi odpowiednik narteksu w bazylice wczesnochrześcijańskiej. Było to miejsce przeznaczone dla katechumenów, którzy $\mathrm{w}$ trakcie Eucharystii mieli prawo przebywać w świątyni tylko na liturgii sło$\mathrm{wa}^{21}$. Katechumenat miał charakter mistagogii, czyli wprowadzania w misterium wiary i zbawienia, a termin ten odnosił się szczególnie do nauk pochrzcielnych,

${ }^{21}$ B. Filarska, Początki architektury chrześcijańskiej, Lublin 1983, s. 19. 
czyli już po przyjęciu sakramentów ${ }^{22}$. Sobór Watykański II powrócił do tradycji mistagogii chrześcijańskiej ${ }^{23}$. Odnosi się do niej także między innymi papież Benedykt Xvi w posynodalnej adhortacji Sacramentum Caritatis, sugerując inicjowanie w parafiach drogi mistagogicznej, która wprowadzałaby wiernych w historię zbawienia, wyjaśniała symbolikę liturgii i sakramentów, łącząc ją z codziennością życia chrześcijanina ${ }^{24}$.

Księga liturgiczna Obrzędy chrześcijańskiego wtajemniczenia dorosłych ${ }^{25}$ oraz odwołujący się do niej często, opracowywany obecnie, Ceremoniał wspólnoty parafialnej $^{26} \mathrm{w}$ rozdziale Mistagogia - metoda formacji liturgicznej wielokrotnie nawiązują do symboliki stopni lub bram dla określenia kolejnych etapów wtajemniczenia mistagogicznego.

Człowiek jest wprowadzany w Misterium poprzez stopnie, etapy i bramy [\$618] [...]. Mówi się wyraźnie o stopniach, etapach i bramach, przez które należy prowadzić człowieka do sakramentów świętych. Chrześcijanin powinien zbliżać się do przyjęcia łaski sakramentalnej jak gdyby wchodził do świątyni. Święte Święty ch, jeśli tak nazwać przyjęcie sakramentu lub innego daru Pana, znajduje się w samym środku, w głębi świątyni. Nie można do niego dojść inaczej, jak przechodząc przez kolejne bramy. [ $\$ 620$ ] [...] Katechumen przebywając je, przechodzi jakby przez bramy lub wstępuje na kolejne stopnie. Pierwszy stopień ma miejsce wówczas, gdy człowiek zaczyna się nawracać i pragnie zostać chrześcijaninem, a Kościół przyjmuje go jako katechumena. Drugi, gdy kandydat pod koniec katechumenatu pogłębiwszy już wiarę, zostaje dopuszczony do bliższego przygotowania do sakramentów. Trzeci, gdy po odpowiednim przygotowaniu przyjmuje sakramenty, przez które staje się chrześcijaninem. Istnieją zatem trzy stopnie, etapy lub bramy, które we wtajemniczeniu chrześcijańskim należy uważać za szczególnie ważne i doniosłe. Tym trzem stopniom odpowiadają trzy obrzędy liturgiczne. Pierwszy - to obrzęd przyjęcia

${ }^{22}$ J. Danielou, H. I. Marrou, Historia Kościoła od czasów najdawniejszych do roku 6oo, [w:] Historia Kościoła, t. 1, red. L. J. Rogier, tłum. M. Tarnowska, Warszawa 1986, s. 68-72.

${ }_{23}$ P. Mąkosa, Terminologiczne podstawy katechezy mistagogicznej, „Roczniki Pastoralno-Katechetyczne" 4 (2012) 59, s. 182.

${ }^{24}$ K. Broszkowski op, Jedność parafii a celebracja Eucharystii w matych wspólnotach $w$ parafii w świetle najnowszych dokumentów Kościoła, „Wrocławski Przegląd Teologiczny” 21 (2013) 2, s. $145-146$.

${ }^{25}$ Wtajemniczenie chrześcijańskie. Wprowadzenie ogólne, [w:] Obrzędy Chrztu dzieci dostosowane do zwyczajów diecezji polskich, Katowice 2009, s. 9-18.

${ }^{26}$ Ceremoniał wspólnoty parafialnej, 3: Formacja liturgiczna, http://www.kkbids.episkopat. $\mathrm{pl} /$ ? id=35 (30.03.2015). 
do katechumenatu, drugi - wybranie kandydatów do chrztu, trzeci - sprawowanie sakramentów [\$621].

Przez analogię do zacytowanej metaforyki mistagogicznej, w przestrzeni granicznej prowadzącej do świątyni w kościele bernardynów w Rzeszowie można dokonać podziału wyznaczanego kolejnymi realnymi (autentycznymi) bramami na: rzeczywistość ziemską i obecność Boga w historii w strefie zewnętrznej na awersach drzwi, tajemnicę wcielenia ukazaną w ewangelii i przedstawioną na rewersie wewnątrz kruchty oraz rzeczywistość sakramentalną - obecność Boga w Eucharystii na drzwiach wewnętrznych. Nawiązanie do bram mistagogicznych w programie ikonograficznym przestrzeni prowadzącej do wnętrza kościoła miało charakter intuicyjny i podobnie bywa odbierane przez wiernych licznie nawiedzających sanktuarium Matki Boskiej Rzeszowskiej pozostające pod opieką ojców bernardynów.

Fundacje rzeźbionych drzwi kościelnych odlewanych w brązie to zjawisko szczególnie częste w polskiej sztuce sakralnej przełomu xx i xxI wieku. Specyfika architektury kościoła bernardynów w Rzeszowie pozwoliła na stworzenie oryginalnej, rozwijającej się w przestrzeni dekoracji zespołu drzwi, niespotykanej w takim wymiarze w żadnej współczesnej realizacji w Polsce.

\section{Bibliografia}

Broszkowski K. op, Jedność parafii a celebracja Eucharystii w małych wspólnotach $w$ parafii w świetle najnowszych dokumentów Kościoła, „Wrocławski Przegląd Teologiczny” 21 (2013) 2, s. 145-146.

Bussagli M., Aniołowie: pochodzenie, historia, ikonografia istot niebieskich, tłum. A. Gogut, Warszawa 2011.

Bystroń J., Polscy święci i błogosławieni wyniesieni na ołtarze przez Jana Pawła II, Pelplin 2004 .

Danielou J., Marrou H. I., Historia Kościoła od czasów najdawniejszych do roku 6oo, [w:] Historia Kościoła, t. 1, red. L. J. Rogier, tłum. M. Tarnowska, Warszawa 1986, s. 68-72.

Duchet-Suchaut G., Pastoureau M., La Bible et les saints. Guide iconographique, Paris 1990. Filarska B., Początki architektury chrześcijańskiej, Lublin 1983.

Fischinger A., Krakowski P., Kościół Bernardynów w Rzeszowie - mauzoleum Ligęzów, [w:] Studia renesansowe, t. 3, red. M. Walicki, Wrocław 1963, s. 150-202. 
Jagiela B., Gosztyła B., Restauracja ołtarza głównego w kościele oo. Bernardynów w Rzeszowie, „Wiadomości Konserwatorskie” 40 (2014), s. 7-13.

Hennig W., Kościół oo. Bernardynów, [w:] Encyklopedia Rzeszowa, red. J. Draus i in., Rzeszów 2004, s. 246-249.

Knapiński R., Titulus ecclesiae. Ikonografia wezwań współczesnych kościołów katedralnych $w$ Polsce, Warszawa 1999.

Majewski K., Z badań nad sztuką Rzeszowa, [w:] Dzieje Rzeszowa, t. 1, red. F. Kiryk, Rzeszów 1994, s. 411-413, 458-468, 487-508.

Mąkosa P., Terminologiczne podstawy katechezy mistagogicznej, „Roczniki Pastoralno-Katechetyczne" 4 (2012) 59, s. 181-190.

Kościoły, klasztory i parafie dawnego Rzeszowa. materiały z konferencji naukowej zorganizowanej dla uczczenia Wielkiego Jubileuszu Chrześcijaństwa, 15-16 XI 2000 r., red. M. Jarosińska, Rzeszów 2001.

Kramiszewska A., Prawdziwie jest to dom Boga i brama do nieba! Opowieść etiologiczna miejsc świętych $w$ zwierciadle sztuki, Lublin 2012.

Ryba G., Katedra rzeszowska 1977-2002. Historia, sztuka, twórcy, idee, Kraków 2007.

Samek J., Porta angusta i nagrobki portalowe w Polsce (zapomniana symbolika wejścia w sztuce), „Folia Historiae Artium” (1980) 16, s. 141-159.

Tokarski W. P. ofm, Kurowska E., Bazylika Ojców Bernardynów w Rzeszowie. Przewodnik, Rzeszów 2009.

Wyczawski E., Krótka historia Zakonu Braci Mniejszych, [w:] Klasztory bernardyńskie $w$ Polsce, Kraków 1985, s. 619-631.

Ziółkowski Z., Michał Archanioł w Piśmie Świętym i życiu Kościoła, Częstochowa 2011. Zaleski W. sDB, Święci na każdy dzień, Warszawa 1989.

\section{Abstrakt}

W latach 1610-1629 z fundacji Mikołaja Spytka Ligęzy wzniesiono w Rzeszowie na miejscu objawień Matki Boskiej kościół, nad którym opiekę powierzono bernardynom. W związku z jubileuszem 50o-lecia owych objawień, przypadającym w 2013 roku, w kościele dokonano szeregu prac renowacyjnych. W kruchcie, która zajmuje dolną kondygnację wieży, na osi na wprost prezbiterium odkryto wejście, zamurowane prawdopodob- 
nie wkrótce po wybudowaniu kościoła, i przebito je ponownie, zgodnie z pierwotnym założeniem. Pomieszczenie kruchty w przyziemiu wieży zajmuje przestrzeń na planie zbliżonym do kwadratu, przykrytą sklepieniem krzyżowym. W każdej ścianie znajduje się otwór wejściowy wypełniający wnękę w grubości muru zamkniętą łukiem odcinkowym. Dwie pary dwuskrzydłowych drzwi z brązu, obustronnie rzeźbionych, prowadzą do wnętrza kruchty z zewnątrz, natomiast kolejne drzwi, również pokryte dekoracją rzeźbiarską, oddzielają to pomieszczenie od nawy. Ich częściowe przeszklenie sprawia, że w kształt pola obrazowego zostaje wpisane całe wnętrze bogatej, manierystyczno-barokowej budowli, tworząc przestrzenny układ scenograficzny, rozwijający się w głąb, aż do tabernakulum i ołtarza głównego w prezbiterium. Z natury rzeczy ruchomy układ skrzydeł pozwala tworzyć zmienne konfiguracje o zróżnicowanym przesłaniu, rozwijającym się w czasie i przestrzeni. Obrazy z historii lokalnego objawienia i postaci miejscowych świętych poprzez przedstawienia i cytaty biblijne stopniowo prowadzą widza do tajemnicy wcielenia. Przestrzeń kruchty, łącząca umiejętnie przekaz ikonograficzny z symboliką i ekspresją formy (m.in. symbolika światła i symbolika materiału) stanowi znaczący element, a zarazem metaforę wtajemniczenia mistagogicznego, dokonującego się podczas przekraczania granicy pomiędzy profanum a sacrum.

\section{Słowa kluczowe}

kościół bernardynów, Rzeszów, mistagogia, przestrzeń, wnętrze świątyni

\section{Abstract \\ The Bernardine church in Rzeszów. Mystagogy of the space leading into the church interior}

In the years 1610-1629, a church founded by Mikołaj Spytko Ligęza was erected in Rzeszow on the site of apparitions of the Virgin Mary, and entrusted to the care of Bernardine monks. In connection with the jubilee of the $500^{\text {th }}$ anniversary of the apparitions in 2013, a series of renovations were conducted in the church; and the porch, which occupies the bottom floor of the tower, built on the axis of the west facade of the building, was rebuilt. Currently, there are two pairs of double bronze doors, carved on both sides, which lead 
to the interior of the porch. Another door, also covered with sculptural decoration, separates the porch from the nave. Its partial glazing inscribes the entire interior of the rich Mannerist-Baroque building into its image field, creating a spatial stage design arrangement developing into the interior, towards the very tabernacle and the main altar in the chancel. Obviously, the moving wing system allows for creating variable configurations with varying messages, developing in time and space. Images of the history of the local apparition and the figures of the local saints gradually lead the viewer through biblical presentations and quotations to the mystery of the Incarnation. The space of the vestibule, skillfully combining the iconographic message with the symbolism and expression of the form (such as the symbolism of the light and the symbolism of the material), constitutes a significant element and, at the same time, a metaphor of mystagogical initiation, achieved when crossing the border between the profane and the sacred.

\section{Keywords}

Bernardine church, Rzeszów, mystagogy, space, church interior 

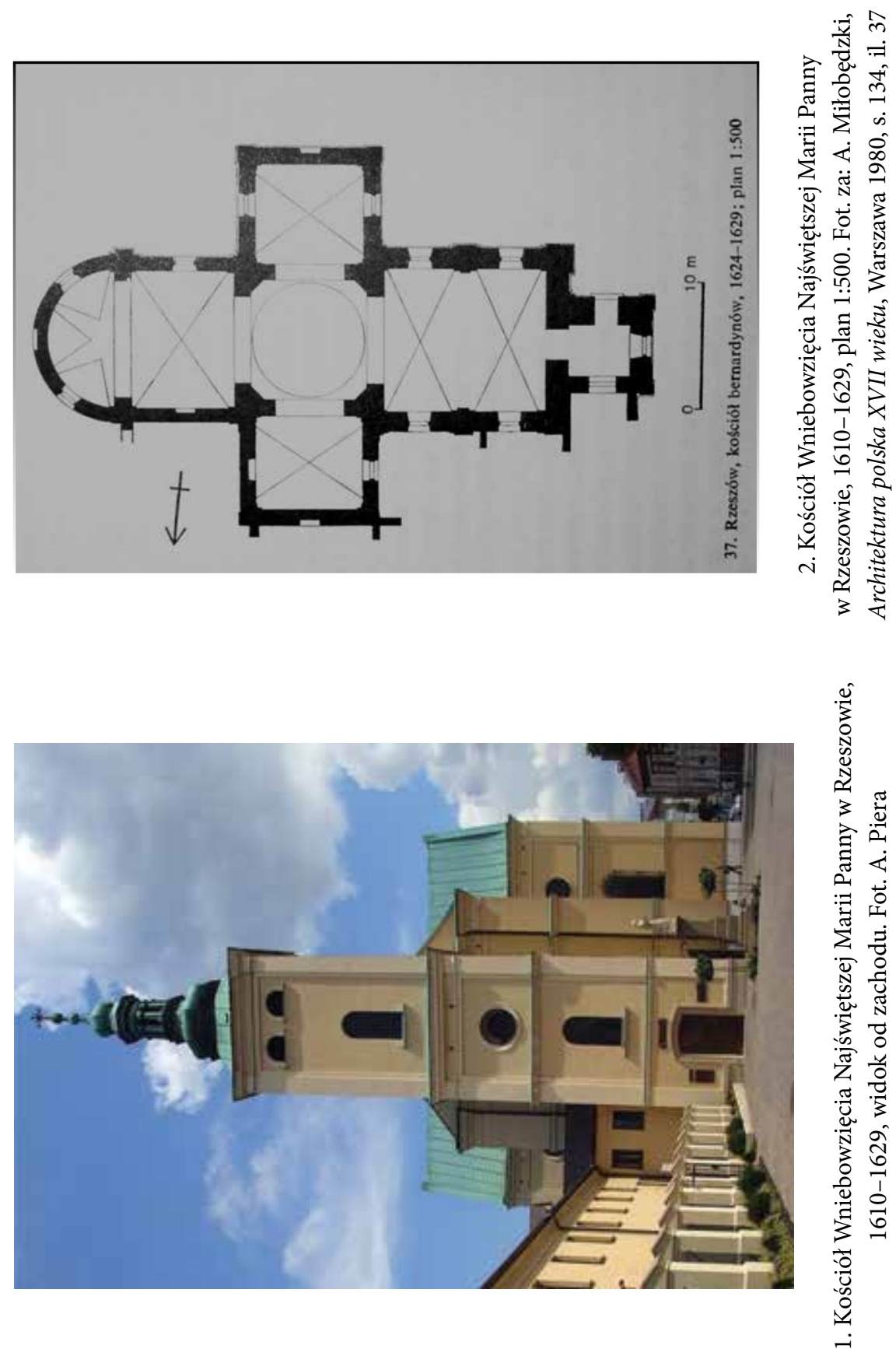


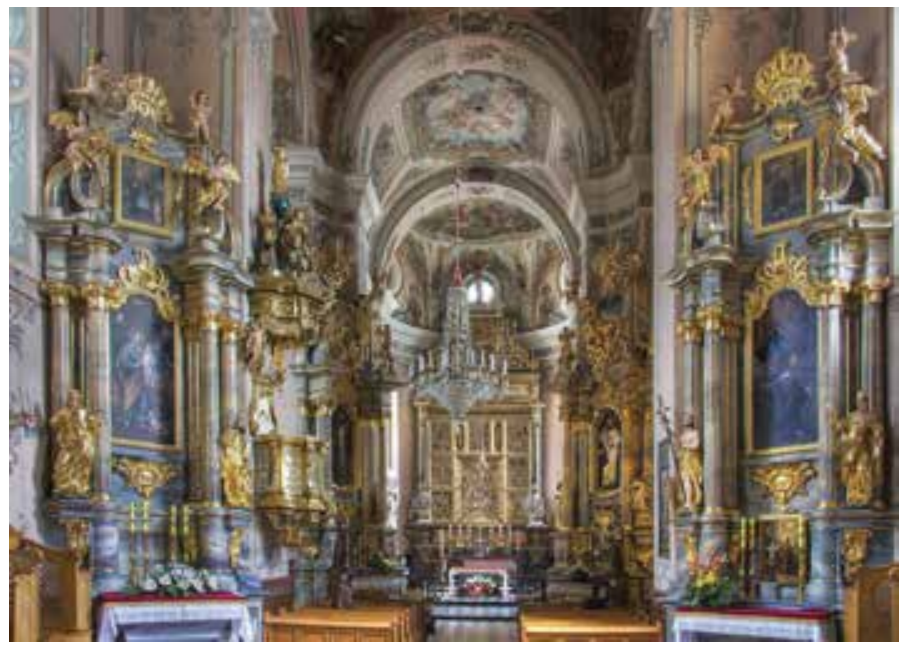

3. Kościół Wniebowzięcia Najświętszej Marii Panny w Rzeszowie, 1610-1629, widok wnętrza ku prezbiterium. Fot. Klasztor OO. Bernardynów w Rzeszowie

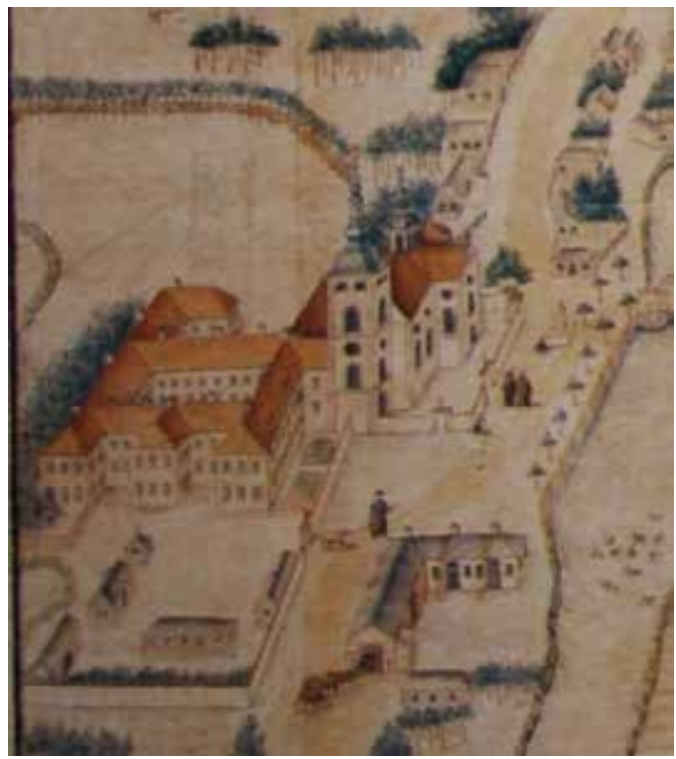

4. Kościół Wniebowzięcia Najświętszej Marii Panny w Rzeszowie, fragm. Planu Rzeszowa K. H. Wiedemanna, 1762, rysunek piórkiem, akwarela, Muzeum Okręgowe w Rzeszowie. Fot. M. Wideryński 

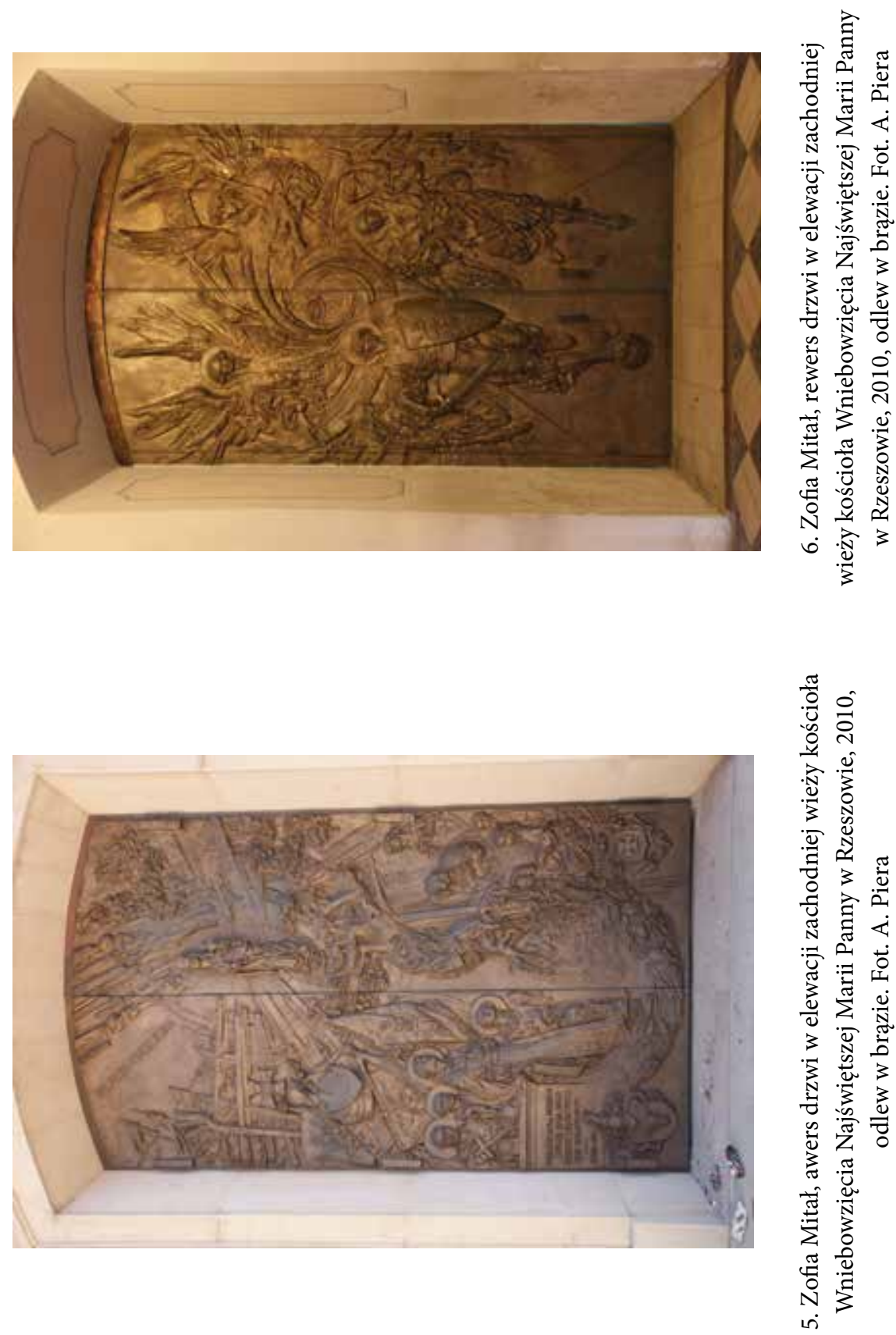

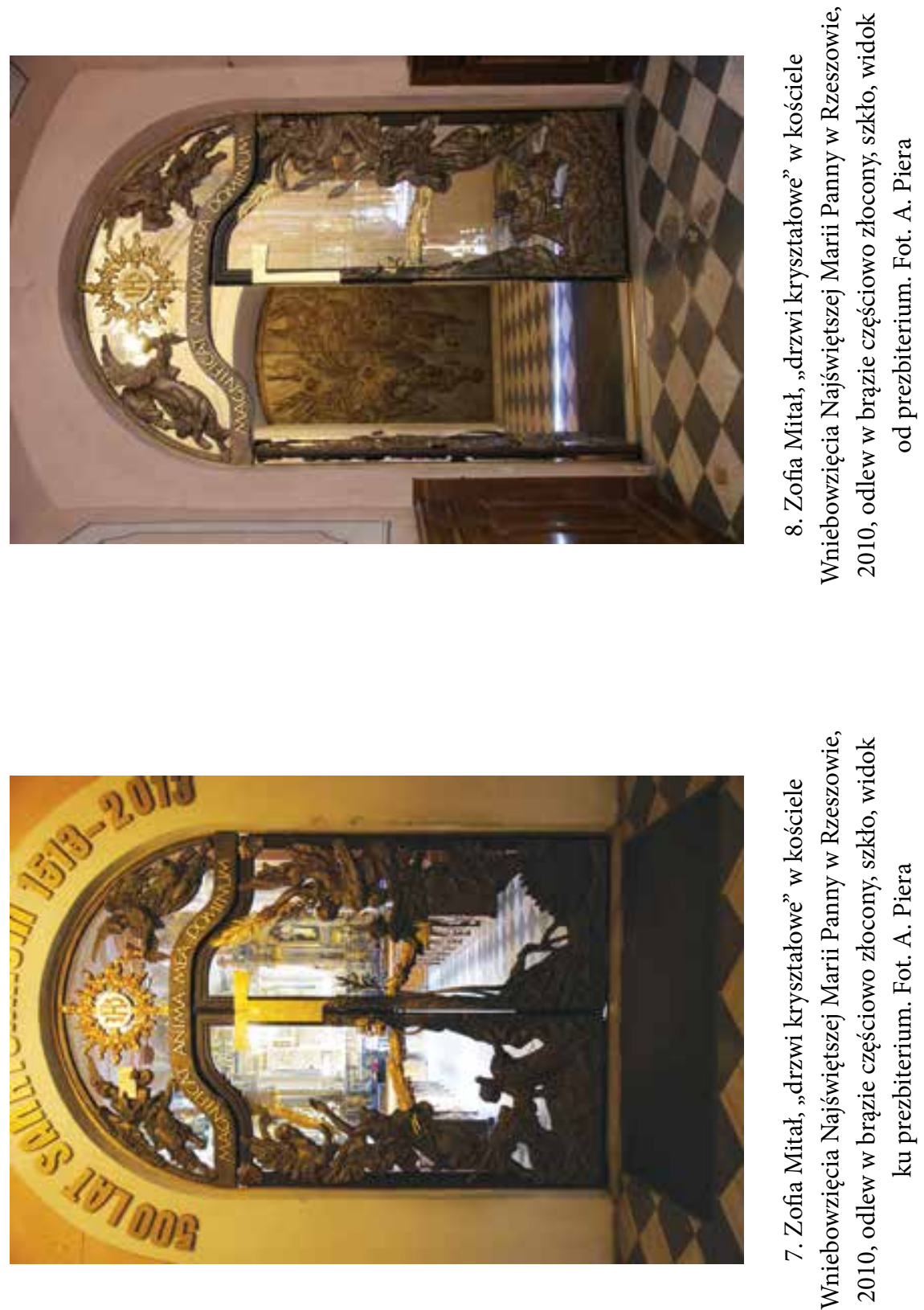


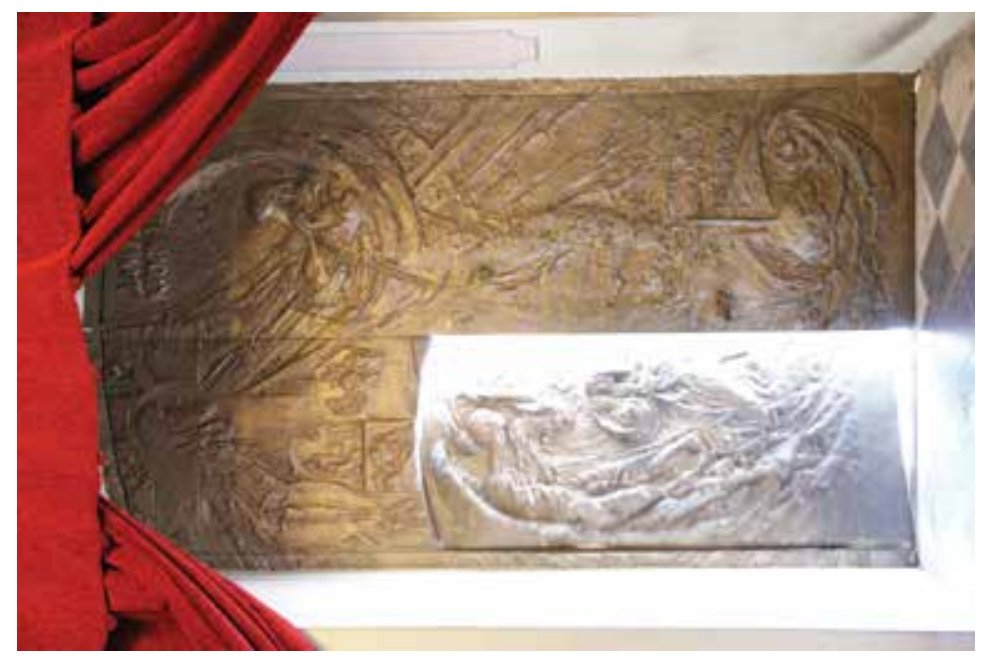

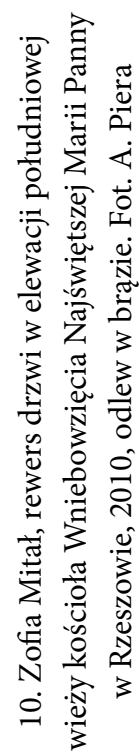
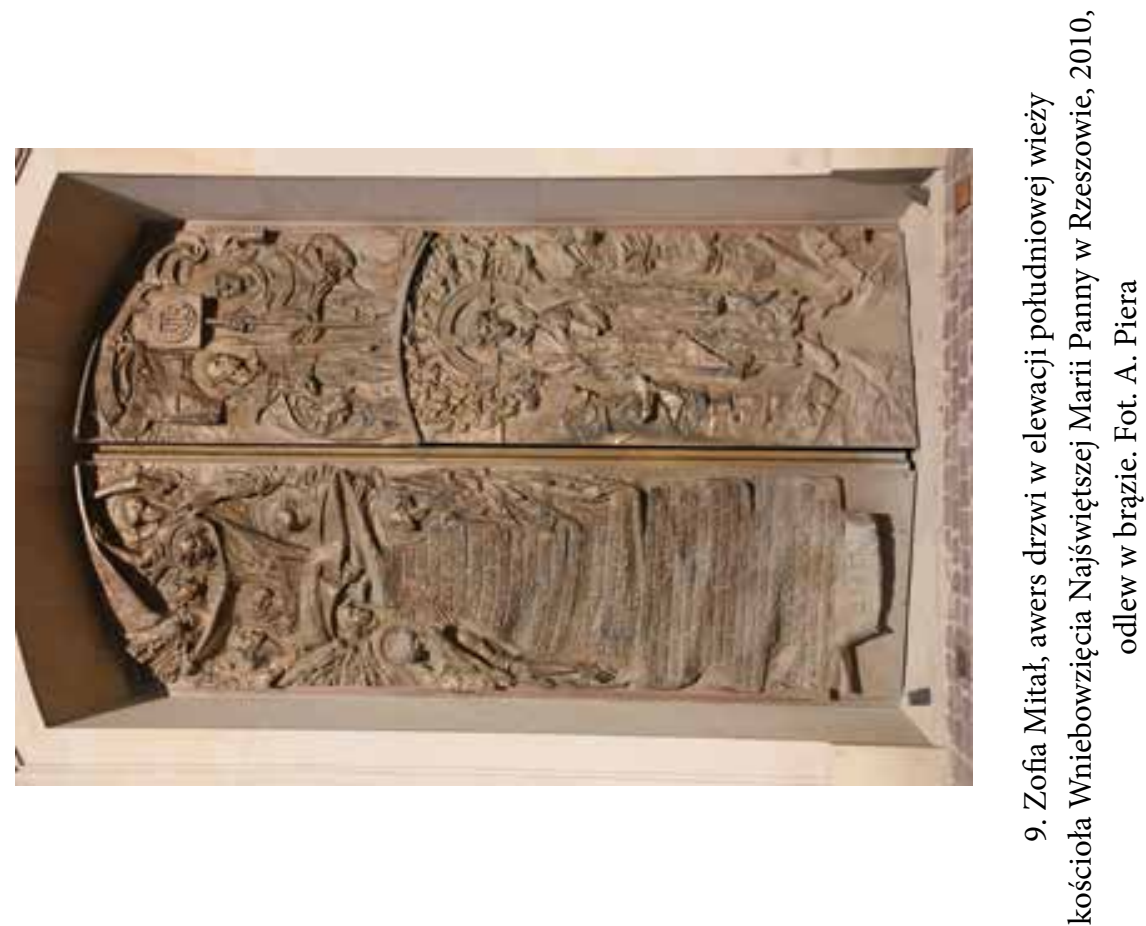


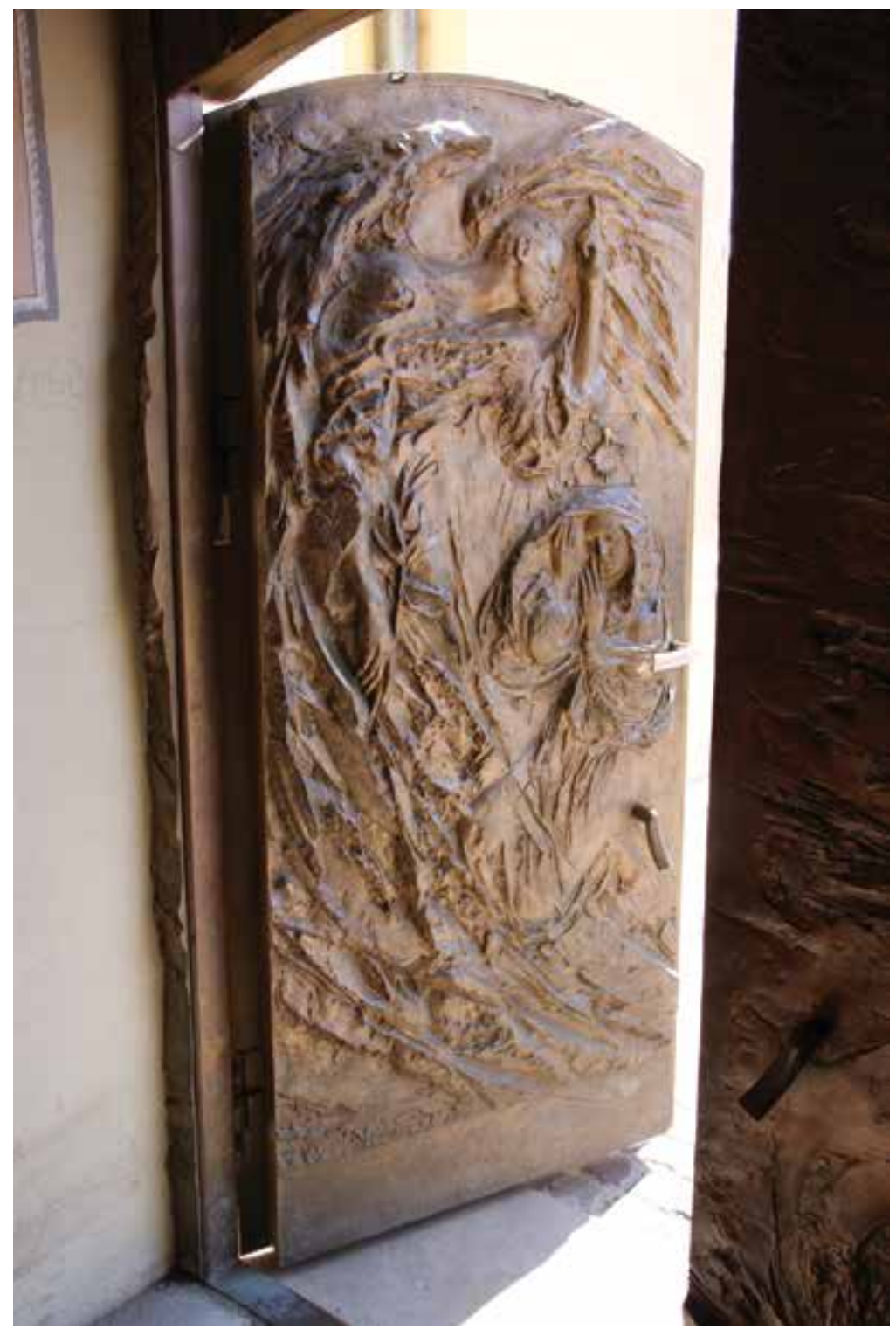

11. Zofia Mitał, rewers furty w drzwiach elewacji południowej wieży kościoła Wniebowzięcia Najświętszej Marii Panny w Rzeszowie, 2010, odlew w brązie. Fot. A. Piera 